\title{
HISTORY AS A SYSTEM OF WRONGS - EXAMINING SOUTH AFRICA'S MARIKANA TRAGEDY IN A TEMPORAL LEGAL CONTEXT
}

\author{
Nico Buitendag \\ Department of Jurisprudence \\ University of Pretoria, South Africa
}

\author{
Neil Coetzer \\ Senior Associate \\ Cowan-Harper Attorneys, South Africa
}

\section{Abstract}

On 16 August 2012, striking miners in Marikana, South Africa were fired upon by the South African Police Service, resulting in the death of 44 mineworkers. For many the incident has signalled a turning point for the country. This paper suggests that rather than a turning point, the tragedy at Marikana is perhaps only the newest instalment in a centurylong cycle of industrial action and government violence in South Africa's labour history. Marikana is thus not a turning point, but rather a restatement of the ineffectiveness of law. The article then attempts a theoretical analysis of these events, as well as the matter of whether Marikana is a true event that brings about political and social change. Although many consider Marikana a "founding myth" for a popular uprising in South Africa, the article cautiously suggests that it is in fact just "business as usual".

\section{Introduction}

On August 16, 2012, the South African police intervened in a labor conflict between workers at the Marikana platinum mine near Johan- 
nesburg and the mine's owners: the stockholders of Lonmin, INC., based in London. Police fired on the strikers with live ammunition. Thirty-four miners were killed. As often in such strikes, the conflict primarily concerned wages: the miners had asked for a doubling of their wage from 500 to 1,000 euros a month. After the tragic loss of life, the company finally proposed a monthly raise of 75 euros. (Piketty 2014: 39)

These are the first words of Thomas Piketty's recently published treatise on global inequality. That a book on economics reflects on the remote mining town of Marikana as its starting point is, at the very least, an indication of the impact that the Marikana tragedy has had on the world to date. Piketty recalls earlier events of 1886 (Haymarket Square) and 1891 (Fourmies) where police had also fired on striking workers. He then ponders: "Does this kind of violent clash between labor and capital belong to the past, or will it be an integral part of twenty-first century history?" (Piketty 2014: 39).

South Africa's industrial relations history is pockmarked with incidents similar to the scenes that played out at Marikana in 2012. That history was shaped by colonial rule (by both the Netherlands and Great Britain), the discovery of precious minerals such as gold and diamonds and, of course, apartheid. It is the very same history which, through the efforts of organised labour as well as socio-political, economic and international forces, led to the dismantling of the apartheid state. Twenty years into South Africa's democracy, it is still beset by symptoms of the past such as inequality, poverty, violence and strikes.

The reasons for violence during strikes are numerous and complex (Ngcukaitobi 2013: 836; Alexander 2014; Mavuso 2014). When examined at its most rudimentary level, the driving forces appear to flow from South Africa's socio-political and socio-economic situation some 20 years after the end of apartheid. As lawyers, we make no pretence in regard to fully understanding these reasons. This is a task gratefully deferred to social scientists. Nevertheless, South Africa's levels of inequality and poverty are well-known and its government's attempts at reducing these 'challenges' (to borrow from the bureaucrat's phrasebook) since 1994 have been slow, misguided and plagued by corruption.

The National Party Government's realisation at the end of the 1980s that apartheid as a social policy was no longer sustainable led to 
a flurry of political activity. After the release of Nelson Mandela and the unbanning of various political prisoners and organisations, such as the African National Congress (ANC), an accord was struck between the various political interest groups. Shortly thereafter an interim Constitution was approved and in February 1996, just about two months shy of two years after the first democratic elections in April 1994, the Labour Relations Act 66 of 1995 ("the LRA of 1995") was promulgated. It was, by all accounts, a radical departure from the previous industrial relations framework. The LRA of 1995 espoused heady values which sought to embody the constitutional ethos of the new South Africa and brought with it protection of the rights of employees against unfair dismissal and unfair labour practices (sections 185 and 186 of the LRA of 1995), a clear preference for bargaining at a centralised, sectoral level (based on the democratic principles of voluntarism and majoritarianism) (section 1 (d)(ii) of the LRA of 1995, Kem-Lin Fashions CC v Brunton \& another (2001) 22 ILJ 109 (LAC) para 19) and extending the right to strike to all employees, provided that certain procedural and substantive requirements are met (sections 64 and 65 of the LRA of 1995). These changes have remained intact to this day despite challenges to the constitutionality of some of these provisions.

The guarantee of the right to collective bargaining and the attendant right to strike are possibly the most important changes brought about by the LRA of 1995. The collective wisdom of the day may have been that if the right to strike were to receive constitutional and legislative protection, the violent behaviour which seemed to characterise most incidents of industrial action would be reduced significantly. This has, however, proven to be a gross miscalculation, as the codification of a right to strike has had little success in reducing levels of violence or the instance of strikes. Nowhere was it more apparent than the Marikana Massacre of 2012 that the more things had changed, the more they stayed the same in South Africa's industrial relations landscape.

This article argues that Marikana is not a 'turning point' in South African history, as some have suggested. Marikana is, at its most elementary level, nothing more than a restatement of the ineffectiveness of the law as a deterrent to violence. Marikana, simply put, constitutes a repetition of historical events in a different temporal context within South Africa's legal system. 1994's democratic elections brought with it constitutionally guaranteed rights which included the right to strike. Set against this backdrop are the expectations of a majority of 
the population which seek to have their lot improved, particularly after more than 20 years of democratic rule by the ANC that promised them as much. The article concludes by arguing that the ineffectiveness of law in resolving problems of inequality will lead to instances of Piketty's $21^{\text {st }}$ century history.

\section{A theoretical journey through past, present and future}

The events at Marikana on 16 August 2012 have impacted upon the South African political landscape, despite the full repercussions not yet being clear. Scholarly output regarding the massacre has trickled out steadily, with at least one author being of the opinion that it is a "turning point in South African history" (Alexander 2013: 605). Other scholars have commented on the solidarity shown by workers despite labour being fragmented (Chinguno 2013: 639), how micro-financiers have enslaved Marikana's miners in debt (Bond 2013: 569), and how the event is a reminder of the apartheid regime (MacShane 2012: 13).

It is interesting to note that no comparisons have thus far been made to the strikes of the $20^{\text {th }}$ century. The socio-economic conditions that triggered those strikes are substantially analogous to those which had sparked the incidents at Marikana. In this section an attempt will be made to place the events of Marikana within a temporal context. Firstly the history of Marikana, meaning the historical context of past violent suppression of strikes in South Africa and also the events of 16 August 2012 as an object of history, will be analysed. History begs of us to engage with questions of memory as well as forgetting. By comparing the relevance of the earlier strikes to future events, one can speculate over the fate of Marikana as an object of future historicity. Secondly, in dealing with the present, a theoretical evaluation of the nature of violence and its inherent relationship with law will be made. The legitimacy of violence within the legal system will be discussed in order to establish possible answers to the question of whether law is capable of dealing with violence such as that at Marikana. Finally, with one eye on the strikes of the past, a projection on the future implications of Marikana will be attempted. The answer to this lies in asking the question of whether the violence of that day qualifies as a true event, meaning one that changes the entire environment in which it occurred. Throughout 
the analysis of past, present and future, recurring themes such as repetition and forgetting will reappear.

\subsection{The past: Remembering justly}

As mentioned earlier, Marikana was not the first time that executive power was used to intervene in industrial action. In 1914, the Union Government of South Africa employed the armed forces to bring a strike over attempts to retrench employees to an end. A few years later the infamous Rand Rebellion, which started as an industrial dispute, resulted in the deaths of some 230 people (mostly miners). The Great Strike of 1946 was organised by the African Mineworkers Union in response to the disparity in wages between white and black miners. The strike led to what became known as 'Bloody Tuesday' when at least nine miners were gunned down by the police. In 1973 some 200000 black workers engaged in a series of rolling strikes. While the strikes were largely peaceful, 12 strikers were killed and 38 injured by police at the Western Deep Levels Mine. It seems that the memories of these events, as our only mode of access to the past have been erased. Instead references have been made to Sharpeville and the Soweto Uprising in order to make sense of Marikana (Ngcukaitobi 2013: 837). While superficially the horror of state violence brought to bear on its own citizenry seems comparable, the comparison is superficial and ultimately misplaced. The manner of dealing with industrial action by the Union government in the early part of the $20^{\text {th }}$ century and the $\mathrm{Na}$ tional Party government thereafter serve as more suitable comparators to the actions of the ANC in 2012. It is a pity that these events seem to have been forgotten or overlooked in the debate around Marikana.

If we are to access the past through memory, it is important to understand the nature of memory. The French philosopher Paul Ricoeur distinguishes between two kinds of memory: mneme is a memory appearing passively, or "popping up", whilst anamnesis is the active recalling or recollecting of a past event (Ricoeur 2004: 91). In this case, when actively enquiring over past events, the mode is one of anamnesis. Memory itself, however, is not neutral. The object of anamnesis, as well as the subject engaged by it, affects the recollection (Ricoeur 2004: 83). This is because memory is not neutral but also dwells in the domain of imagination (Ricoeur 2004: 105), and is therefore also symbolic (Ricoeur 2004: 285). The reasons for this additional 
layer of meaning, the symbolic and the imagined, are necessarily present because recollection is, by definition, the conjuring of the absent.

Why then is it important for us to recall past events? Why is it necessary to recall violent and unpleasant events such as the strikes of the $20^{\text {th }}$ century? Why is it important for purposes of the law? We quote Ricoeur: "Extracting the exemplary value from traumatic memories, it is justice that turns memory into a project; and it is this same project of justice that gives the form of the future and of the imperative to the duty of memory" (Ricoeur 2004: 1362).

For Ricoeur, justice is the virtue that is turned to all other virtues. If all virtues are self-referential then justice is the exception, the one virtue that is the component of Otherness that breaks the cycle of selfreference. Thus if recollecting the violent episodes of the past, the duty of the virtuous memory is to do justice to an Other (Ricoeur 2004: 1375). This kind of memory turned toward justice arises out of many facts. One is that we are indebted to those that have come before us, and obligated to respect the past Other. Ricoeur raises an important point however: out of all those to whom we are indebted to remember, the most important are the victims.

Why then is it that previous incidents of Marikana in the $20^{\text {th }}$ century have been forgotten? Not only have these events not been recalled after Marikana, but should these memories not have prevented it from happening in the first place? It seems that instead of remembering, history has chosen to repeat itself. For Ricoeur, this repetition marks the forgetting of the past (Ricoeur 2004: 6611). It often feels easier to forget past traumatic events. As Zizek (who will be discussed in greater detail below) notes, the victim of trauma in a certain way survives his own death, and re-emerges as a brand new subject (Zizek 2014a: 98). It creates a decisive break in the temporal continuity, cutting the narrative that stretches from the memory to the new identity. This is perhaps one explanation for why the violent past is forgotten. But as Ricoeur reminds us, the first lesson of psychoanalysis is that trauma remains even when it is inaccessible or unavailable to memory (Ricoeur 2004: 6611).

Another danger exists in this kind of forgetting, especially when it is a forgetting imposed through ideology (Ricoeur 2004: 6662). The danger lies in the fact that memory becomes abused through the reconfiguration of narratives of the past, by shifting the emphasis and recasting the protagonists and their actions. This has happened in the 
past with the strikes of a century ago, these events having been largely wiped from the collective conscience, which today has made it difficult to draw the obvious narrative history of industrial unrest being met with state-sanctioned violence, and has allowed some to obfuscate the real fault-lines of the problem in favour of their own political or academic agendas. The memory of Marikana itself is already in danger of this kind of manipulation through the nature of the very inquiry that is necessarily needed to make sense of the massacre. For as Ricoeur writes:

[t]he prime danger, at the end of this path, lies in the handling of authorized, imposed, celebrated, commemorated history — of official history. The resource of narrative then becomes the trap, when higher powers take over this emplotment and impose a canonical narrative by means of intimidation or seduction, fear or flattery. A devious form of forgetting is at work here, resulting from stripping the social actors of their original power to recount their actions themselves (Ricoeur 2004: 6673).

\subsection{The present: Law and violence}

The history of violent confrontations between miners and the South African government has been discussed in the previous section, taking the position that justice requires of us to remember these incidents and that care should be taken not to have this memory manipulated by power. In this section the point-of-view moves from the past and into the present. Because discussing the past already places the incident at Marikana as a present projection of a future memory, it is also important to ask the questions that crop up in the here and now regarding the episode. These are questions regarding the legitimacy of violence in law, by law and against law. How are we to understand these phenomena in principle, this "tragic dimension of action" (Ricoeur 2000: 154)? Is it true, as Chinguno claims, that "in South Africa democracy is significantly characterised by the persistence of violence in claim making" (Chinguno 2013: 639)?

One possible analysis to turn to is the critique of violence by Walter Benjamin (Benjamin 1978). He notes that violence is always a means to an end and not an end in itself. This is an important distinction for him, for it is important if one is to offer a pure critique of violence, to be able to judge violence purely as a means without reference to the justness of its end. For Benjamin this is also the difference between 
natural law and positivist approaches to violence in law: in the case of natural law, violence is seen as a "raw material" of nature which is not at odds with the law if used for just ends, a view which he flatly rejects (Benjamin 1978: 278). On the other hand a positivist approach holds that violence is a mere product of history and that just (legal) means necessarily lead to just ends. Whilst natural law espouses a justice that is achieved violently outside the legal system, positivism espouses legality through procedural guarantees. It is enough to convince Benjamin that a critique of violence should be based on a positivist basis, because it is concerned with means and can distinguish between different kinds of means, and thus kinds of violence. This, however, appears to be a false dichotomy between means/ends and natural law/ positivism, for means and ends are not necessarily incompatible. It is, for instance, entirely possible for just means to lead to just ends. If it is possible for positivism to distinguish between means on the basis of procedural legality, then it is held that a natural law approach can distinguish between means based on the virtue of justice which, as has been stated earlier, is exactly the virtue that cracks open the circular self-contained reasoning of other virtues such as due legal process. It does not mean that violence cannot be judged purely without reference to its end. Rather it opens the means to its full contextual complexity and can allow us to judge it by norms other than pure legality. After all, as Benjamin himself concedes, positivism can only pass judgment over the meaning of violence but not its value (Benjamin 1978: 279).

Law cannot (and as we will see, would prefer not to) give an exhaustive list of circumstances in which violence can legitimately be employed. Thus in order to be sanctioned, violence must justify its origin from a historical point (this in itself already calls for an analysis outside the narrow ambit of positivism, and demands a multi-disciplinary natural law approach). In general law is threatened and undermined by a violent populace and Benjamin states that "legal ends cannot be maintained if natural ends are anywhere still pursued violently" (Benjamin 1978: 280). The threat of unsanctioned violence is the very fact that it exists outside of the law, and the monopolisation of violence by the state is not to safeguard legal ends, but is in fact an attempt at preserving the law itself.

There are, however, still forms of sanctioned violence that are nevertheless a major threat to the legal system, the greatest example of these being the right to strike. Other than the state, organised labour 
is the most powerful legal subject entitled to exercise violence according to Benjamin. This is true despite the fact that a strike is generally depicted as non-violent and a means to escape violence from an employer. According to Benjamin the very reason a state allows sanctioned strikes is a concession that contradicts its own interests, in order to forestall violence that it is afraid to oppose (Benjamin 1978: 281). This uncomfortable position is illustrated in how labour will always appeal to its right to strike, whilst the state will usually claim that the right has been abused. This is how it can happen that a state meets strikers' violence, as in Marikana, with violence of its own. For Benjamin this represents "an objective contradiction in the legal situation, but not a logical contradiction in the law". Chinguno on the other hand sees violence as subverting capital's attempts at fragmenting labour by enforcing solidarity in violence (Chinguno 2013: 641).

But what happens in the aftermath of a violent episode such as that of Marikana? Benjamin points out that after violence there must usually be a "peace ceremony" (Benjamin 1978: 283). It is the legal sanctioning of the end of a conflict. In this case the Marikana Commission seems to be the first step towards such a moment when a legal sanctioning of the end of violence occurs (subject to the caveat of official history that is discussed in the previous section). The point of this sanctioning of the end of the event is exactly to recognise the new conditions as a new law (Benjamin 1978). It reminds us of Ricoeur, where the restatement of order exactly symbolises a forgetting of the past and the birth of a new subject, but still carrying the hidden traumas that cannot simply be wished away and dooming us to repetition. A violent event, such as Marikana, has a law-making character. This is the reason for the danger such external, unsanctioned violence poses to the legal system: it threatens to declare a new law. It is this lawmaking character of violence that states fear (Benjamin 1978).

As has been stated above, and has been seen in Marikana, extra-legal, law-making violence is often met with violence from the state. This differs from extralegal violence in that it is not in order to achieve natural ends, but rather to achieve legal ends, usually that of compliance to the state and its legal system. This makes state violence a law-preserving species of violence (Benjamin 1978: 284). When the state acts violently it is not in order to punish infringement of the law, but to re-state and re-affirm the law. Hyslop highlights this, arguing that Smuts used military power in the 1920s to generate and normalise a 
legal order which is based on the practices of martial law, coupled with a militant police force, in order to fight against social radicalism (Hyslop 2009: 237). This "deep anti-capitalist militancy" was a threat from Afrikaners who had suffered emotionally and economically under the Second South African War, and the fact that Afrikaner males had the vote was not sufficient to provide them with a sense of social participation sufficiently strong in light of the material disadvantage they suffered compared to Anglophone South Africans. Again one is struck by the similarities between the circumstances leading up to and including the violence of 1922 and 2012. In both cases franchised workers felt alienated by their governments, and like Kafka's man waited for justice before the door of law, but were never allowed in. In fact, it might even be possible to use Hyslop's analysis of 1922 to argue that it had paved the way for Marikana through normalising martial law and by "a blurring of the line between political and military forms of power" (Hyslop 2009: 246).

Benjamin echoes this problem in the case of state violence as exercised by the police. While police violence might be for legal ends, the police tend to have a wide authority to decide on whether to mobilise this violence (Benjamin 1978: 286). It can thus be said to be exempted from the conditions of both law-creating and law-preserving of violence. Therefore it cannot simply be claimed that police violence is a restatement of general law. Instead "the 'law' of the police really marks the point at which the state, whether from impotence because of the immanent connections within any legal system, can no longer guarantee through the legal system the empirical ends that it desires at any price to attain" (Benjamin 1978: 287).

For Benjamin the class struggle is a pure means of violence. He approvingly quotes Sorel for making a distinction between a political and a proletarian strike (Benjamin 1978: 291). Their relationship to violence is also opposite: a political strike aims to strengthen centralised state power, to silence opposition and to issue decrees. It is essentially power changing hands from one privileged group to another. The proletarian strike on the other hand aims to destroy state power. Its members see every reform by the government as bourgeois and insufficient. Whilst the political strike causes a change in labour conditions, with work to be resumed after modification, the proletarian strike is only prepared to resume a wholly transformed work. Whilst the former is lawmaking, the latter is anarchistic.

Thus the function of violence in law-making is twofold. First it 
uses violence as a means toward the end of what is to be established as law. This new law is not a dismissal of the violence that preceded it, but instead embodies the power it holds after the violent act. As Benjamin notes, "law-making is power making and, to that extent, an immediate manifestation of violence" (Benjamin 1978: 295). If justice can justify an end, power justifies law-making. The peace agreement after a violent act, in establishing a new law, also establishes power.

There is, however, a paradox in the new law of law-preserving violence: it weakens the power and law-making violence it represents, by suppressing counter-violence (Benjamin 1978: 300). It lacks what Ricoeur calls a "just distance between two acts of violence" (Ricoeur 2000: 149). It might win many battles, but ultimately sets itself up to lose the war.

\subsection{The future: Do we have a revolutionary event?}

In the previous section we moved from the past to the present, trying to understand the relationship of these acts of violence against striking miners with law on a theoretical level. Under Benjamin's analysis the proletarian strike at Marikana could either be law-creating violence, or the mobilised force by the police could be law-preserving violence. A large part of identifying which is correct will be in how the history of the events will be remembered and who will be in control of its narrative. With the insight of Ricoeur on how to engage with the past, and the contribution of Benjamin on how we can understand our current situation theoretically, we approach the final tense of our triumvirate, namely the future. What will the legacy of Marikana be? Is it fated to be forgotten like similar incidents in our past, or is it a turning point, a true event (Alexander 2013)?

The Slovenian philosopher Slavoj Zizek asks if all things are connected with causal events, such as the history of continual mining exploitation that has led to violent encounters with the state (acting on behalf of global capital), or whether there are certain things that seemingly happen out of nowhere. Can an event occur without sufficient rational reasons (Zizek 2014a)? He invokes Heidegger, for whom an event is not something that happens in reality, but is instead a new "epochal disclosure of Being", the emergence of a new world (Zizek 2014a: 30). Like the trauma that completely destroys the narrative continuity of the past, it is a rupture that draws a line and introduces pain, 
suffering and division. Zizek reminds us of the notion of trauma: a true event is a traumatic intrusion which is unacceptable to the status quo (Zizek 2014a: 78), but as Ricoeur reminds us, this trauma is destined to resurface and doom us to repeat the (forgotten, or perhaps washedaway) past. This repetition is, however, not an exact replica of the old content, but is in fact itself a gesture of erasing the substantial content of the past. It is the act that becomes constitutive of the dimension of subjectivity, that is, the new post-traumatic identity (Zizek 2014a: 98).

According to Zizek a true event such as this, whilst introducing no "new content", changes its whole environment through restructuring the past. This is made effective through the fact that the present can already place itself in some historical context through the narrative device of projecting itself as an object of future memory. This allows the present to able to reflect upon itself (Zizek 2014a: 139). This is also where the present has the power to change the past: the new information introduced changes the links, causes and actions between events and actors; the narrative is changed and the new event rearranges its balance. We can only interpret retroactively, and a new event changes our interpretation. And it is exactly through this retroactivity that causality becomes disturbed. According to Zizek, a true event retroactively causes its necessity (Zizek 2014a: 145). In other words, it is the very act of observing that can elevate a mere incident in the past to the status of an event (Zizek 2010: 105). The incident nonetheless becomes a concept that "acts as a structuring principle that displays dynamics of its own".

So it is in future projection that this radical change of the environment is possible: the proper moment of subjective transformation does not occur at the act, but at the moment of declaration. As Ricoeur states, "political judgment aims not at supressing, but at justifying the particularity of historical events" (Ricoeur 2000: 104). The truly new emerges through narrative, the reproductive retelling of what happened, which opens the space to act in a new way. When a worker participates in a strike, it is only afterwards in the retelling that he recounts it as an act of class struggle, and subjectively and performatively casts himself as a revolutionary. It is only after this that he can continue to act as a revolutionary (Zizek 2014a: 150). Zizek illustrates the insignificance of an event itself when compared to its effects, by noting how Wagner was correct in dealing with battle or conflict in very short scenes or even off-stage. This violence is a symbolic break in the present 
between a much more important past and future. It is suggested that the problem at hand is not so much the violent event itself, but what we do with it afterwards.

For in a true event, it is not that the facts change. What changes are the very parameters by which we measure change. It changes the environment in which the facts appear. A violent strike such as Marikana will only become a true event when it gives rise to the commitment of the collective subject to a new universal emancipatory project, and sets in motion the restructuring of society. This has so far not happened in South Africa. The change that has been attempted, such as renaming cities and streets, has not erased the past but instead looks to have been impotent failures at getting rid of the past (Zizek 2014a: 186).

\section{The importance of Marikana in a temporal context}

Viewed against this backdrop, one could reasonably conclude that Marikana was a product of a dice loaded by those who forgot. That this happened again in 2012 - some 18 years after the demise of apartheid and the introduction of a revised voluntarist, majoritarian industrial relations system - is worth considering.

Sir Otto Kahn-Freund, in his seminal work on British industrial relations, asserts that there is a basic nexus between collective bargaining and labour law (Davies and Freedland (eds) 1983: 13-28). At its most basic level, Kahn-Freund posits that bargaining is inherently unequal between those who are "bearers of power" (employers) and those who are not (employees) and consequently, the law can do little to equalise any imbalance in the bargaining relationship, which by its very nature operates vertically (Du Toit 2007: 1406-1407). The natural consequence of this is for employees to organise themselves into a collective unit for purposes of collective bargaining and to use, as their primary weapon, the withholding of their labour in order to achieve their objectives. In this way, collective bargaining seeks to tilt the vertical relationship onto a horizontal paradigm. Kahn-Freund's theory postulates that the law's role in collective bargaining is one of abstentionism or laissez-faire, leaving employers and employees to determine the equilibrium of their relationship through a system of voluntary collective 
bargaining. The law should, according to Kahn-Freund, only serve to protect the institutions of collective bargaining themselves since governmental intervention is anathema to any autonomous system of collective bargaining. This is best phrased by Kahn-Freund himself in the following passage: "The main object of labour law has always been, and we venture to say will always be, to be a countervailing force to counteract the inequality of bargaining power which is inherent and must be inherent in the employment relationship" (Davies and Freedland (eds) 1983: 18).

South Africa's industrial relations policy, at first glance, appears to be rooted in the classical Kahn-Freundian understanding of collective bargaining. But, as Du Toit points out, "the picture has become more complicated since then". He points out that "in its classical sense, perhaps, 'collective laissez-faire' could only ever have existed under the conditions of relative stability and sustained economic growth experienced in industrialized countries during the 1950s and 1960s" (Du Toit 2007: 1407).

The birth of true democracy in South Africa brought with it sweeping changes to the structure and character of government and its attitudes towards organised labour. What was previously a regime constructed to engineer laws to safeguard the economic interests of a privileged minority quickly evolved into a democratically elected government representing the majority of the population that, amongst other things, attempts a tricky balancing act in trying to appease a tripartite alliance which includes both communist and workers' blocs. The ANC government's close relationship with organised labour means that it operates from a compromised position, rendering any notion of true laissez-faire bargaining, in Kahn-Freund's classical view, illusory. In addition, Du Toit mentions that:

In one sense, the impact of collective agreements on labour markets and increasingly fragile economies was simply too great to be left entirely to the self-interest of trade unions and employers. Starting with the battle to contain inflation and government spending amidst growing international competition, the autonomy of collective bargaining became increasingly circumscribed by incomes policies, social pacts, tripartite institutions and other devices aimed at bringing bargaining outcomes into line with broader policy objectives.

But for all the advancements of the law which gradually loosened the 
authoritarian grip of government over organisation of black workers and trade unions, what have those same workers plying their labour on the mines achieved since 1994? For the past 20 years, the mining industry, as the flagship of South Africa's economy, has faced the unenviable prospect of ensuring South Africa's continued wealth while advancing the notions of equality and liberation espoused by the Constitution. In reality, little has changed on the mines. The National Union of Mineworkers (NUM) remains the majority union in the mining industry (although the events at Marikana have resulted in its dominance being usurped by the Association of Mineworkers and Construction Union (AMCU) in at least the platinum mining sector) and negotiates with the Chamber of Mines at a sectoral, centralised level. Employees of Lonmin earned little more than R4 000,00 (\$342) per month at the time of the Marikana massacre. Miners, as well as other unskilled or low-skilled employees across South Africa's economically active population, are still effectively viewed as disposable labour due to the high levels of unemployment where labour supply easily outstrips demand. It follows logically that those high levels of unemployment serve to further weaken any bargaining power which those who are employed may hold and for those reasons, unions have sought to entrench their interests by concluding collective agreements which effectively keep minority unions and the unemployed in their imbroglio (see section 18 of the LRA of 1995; Brassey 2012: 1). The Congress of South African Trade Unions (COSATU), in occupying its place in the tripartite alliance, has advocated industrial action as the panacea to free the workers (and, it follows, not the unemployed) from the chains of poverty. Such an approach is inherently flawed for at least two reasons. Firstly, unions are concerned solely with those persons who are employed and will, in theory, act in the best interests of its members who are already employed. Calls for jobs from the unemployed are therefore of no concern to unions who, under the LRA, are able to take measures to safeguard the employment of its members against the jobless (Brassey 2012: 7). Secondly, employers are concerned with production and their shareholders (at least theoretically) not the welfare of its workers. Regardless of moral or ethical objections, employers who are subjected to constant threats or actual instances of industrial action will call for increased mechanisation, disinvestment and restructuring to ensure profitability.

NUM, as a member of COSATU, has a familial relationship with the ANC government and as a result, collective bargaining in the mining 
industry prior to the Marikana massacre appeared to assume a political, almost mechanical, quality. In those circumstances, it was easy for NUM to have become complacent in regard to the grievances of its members, which were not being attended to with the expected care and attention shown by previous generations of NUM shop stewards. In May 2012, just a few months prior to the Marikana massacre, the Mail and Guardian, a South African newspaper, reported that Frans Baleni, the General Secretary of NUM, earned a salary of approximately R105 000,00 per month (The Mail and Guardian, 31/05/2012). Brassey, in contrasting the position of unions in the early 1970s with that of the post-1995 era, states poignantly that:

All this has been exchanged for a system that is quite the opposite. Now the emphasis is on central bargaining, union officials and fulltime shop stewards are well paid, the union head office makes decisions on behalf of the membership, and there is nothing to fight over but money. In often perfunctory bargaining council negotiations, the claims of the poor are being sacrificed to service special interests. As often as not, a union official is to be found, not delivering rhetoric at a township meeting, but arguing some knotty issue of estoppel within the stately portals of the Labour Court or the well-appointed offices of the CCMA. In this environment, where little is left to fight over and the bond with the union bureaucracy is tenuous, workers can be forgiven if their loyalty becomes tenuous. Replacing one union with another becomes easy and replacing institutional bargaining with shop-floor activism becomes equally so. Marikana-type anarchy is the, seemingly inevitable, result; the only surprise is that it took such a long time in coming. (Brassey 2013: 833).

This was possibly the biggest factor which contributed to the everwidening gulf between workers and NUM. It resulted in a challenging of the status quo by the employees at Marikana and a truly revolutionary situation whereby employees took up the cudgels and vowed to continue the struggle on their own for what they perceived to be a living wage. AMCU has subsequently seized the initiative and stepped into the void left by the rejection of NUM and is gaining momentum as the union of choice for workers across the mining sector.

It is important, however, to understand that Marikana did not happen in a vacuum. The cracks on South Africa's democratic facade had begun to appear several years before the workers in Marikana 
took to the koppie and had, in any event, been simmering below the surface for several years even before that. In 2007, in the reported case of Food \& Allied Workers Union on behalf of Kapesi \& Others v Premier Foods Ltd t/a Blue Ribbon Salt River (2012) 33 ILJ 1779 (LAC) workers at a bread factory engaged in levels of violent behaviour which had not been seen since the Rand Rebellion:

Non-strikers were harassed and intimidated. Employees were visited at their homes by persons who threatened them with physical harm and death. Relatives of non-strikers were also visited in this manner and informed of what would be done to the family members working at the bakery. One female non-striker was dragged from her home at night and assaulted with pangas and sjamboks.

The vehicle of a non-striker was set alight and destroyed. Shots were fired on this occasion. A neighbour of the non-striker was able to identify the perpetrators. He was subsequently shot and killed near his home. Houses were petrol bombed. Threats to kill senior management were made. Some employees and the senior management group were provided with security guards. A shot was fired through the security guard's vehicle parked outside of the home of Lavery, the regional manager.

Delivery vans were held up and the daily takings were robbed as were personal possessions and money of the drivers and staff. A state of lawlessness prevailed. The cost of increased private security escalated and non-strikers went about their business knowing that they, their families, property and possessions were in a state of danger. (paras 4-6 of Judgment).

In December 2011, only some eight months before Marikana, similar scenes played out in the affluent suburbs of Fourways in Gauteng where employees of Tsogo Sun engaged in a picket which descended into criminal behaviour outside the premises of Montecasino, a popular entertainment and gambling destination:

Regrettably, the picketing that occurred was anything but peaceful. In the founding papers, the applicant averred that the individual respondents were acting in breach of the picketing agreement by engaging in a variety of criminal acts, including assault, theft, malicious damage to property, and blocking access to and egress from the applicant's premises. The conduct described in the founding and supplementary affidavits includes the emptying of rubbish bins onto 
the road outside Montecasino, burning tyres on the road, blocking the road with 20 litre water bottles, throwing packets of broken glass onto the road, throwing bricks at members of the SAPS, damaging vehicles, dragging passengers from vehicles and assaulting them, rolling concrete dustbins into Montecasino Boulevard, damaging patron's vehicles, and assaulting persons in the vicinity of Montecasino. The applicant's attempts to resolve the issue of strike related violence by agreement with the first respondent failed - an undertaking given by the first respondent at the applicant's request proved to be worthless. Ultimately, intervention by the SAPS was necessary, but even this did not deter the individual respondents. (Tsogo Sun Casinos (Pty) Ltd ta Montecasino v Future of SA Workers Union \& Others (2012) 33 ILJ998 (LC) para 4).

At the time of writing this article, the Communication Workers Union (CWU) had recently ended its three-month long strike which resulted in the wholesale interruption of South Africa's postal services. A few months prior, the National Union of Metalworkers of South Africa (NUMSA) embarked on an industry-wide strike in the metals and engineering industries. In January 2014, approximately 70000 workers organised by AMCU in the platinum industry downed tools for a recordbreaking six months. While the strike by AMCU on the platinum belt was relatively peaceful, the strikes by NUMSA and CWU were characterised by violence, intimidation and criminal acts such as damage to property and even, most disturbingly, cruelty to animals (IOL 3 July 2014; EWN 3 July 2014). South Africa's labour law reports and news media are replete with similar stories. Brassey, in an article published shortly before the Marikana massacre, mentions that "murder and arson are far from rare in South African strikes, and assault and intimidation are pervasive" (Brassey 2012: 10). The use of this violence by employees should be relatively obvious - the use of violence in a strike places immediate economic pressure or 'duress' on an employer to increase its wage offer (Myburgh 23 July 2013). In order to bring an end to the violence, the employer is required to make a wage offer informed by the violence rather than by the forces of supply and demand which (usually) results in artificially inflated and unsustainable wage increases.

Ironically, since 1994 the South African Police Service (SAPS), perhaps in a deliberate and concerted attempt to shake its image as the iron-fisted enforcers of the apartheid regime, has been the one 
party actively practising the refrain of laissez-faire. Brassey mentions with reference to post-1994 SAPS involvement that the responsiveness of the SAPS to industrial violence has been questionable:

The easy response is to reproach the police for failing to do their duty. In the past, they were greatly to blame - their response to strike violence, when not openly sympathetic, was often one of indifference or impotence. (Brassey 2012: 10)

It would appear that in the years immediately following democracy until the Marikana massacre, the SAPS, staffed to a large extent by persons from the same group of the previously oppressed majority, identified with the plight of those workers. This too, in our view, appears to be a compromised position for the SAPS. Consequently, the use of violence in South African industrial relations appears now to be the exclusive preserve of organised labour, rather than government. The SAPS routinely decline to enter the fray in industrial disputes, even in circumstances where criminal conduct is clearly present, on the unconvincing and incorrect understanding that industrial disputes are of a civil (and not a criminal) nature. The image of black policemen firing on black workers at Marikana therefore represents the anomaly in the postdemocratic period.

The 1995 LRA's framework has, despite its radical departure from apartheid labour legislation and despite it being the proud blueprint for a new democratic industrial relations system, done little to improve or even alter South Africa's industrial relations climate. Unemployment rates have remained largely stagnant for several years. Indeed, as Brassey argues, much of this must be attributed to the LRA and its emphasis on majoritarian bargaining which permits majority parties in a bargaining relationship to act as cartels, setting wages at such a high level that entry into an industry is made far less attractive. The lack of any real change through labour legislation has led an academic, William Gumede, to question whether South Africa has made any progress at all:

It's hard to overestimate the impact that scenes once associated with apartheid will have now that they are replayed under a black, democratic government. Marikana has shown that a black life, 18 years after racism was supposed to have been banished, still counts for very little, and that the inequality between the rich (mostly white) 
and the poor (mostly black) has remained largely unchanged. (De Villiers (ed), 2013: 2).

The use of violence during industrial action is an indication of, amongst other things, the inadequacy of the LRA of 1995 both as a positive controlling mechanism and as a tool to achieve just and equitable ends. In this sense, despite the gains made by organised labour over the past 100 years, the law has been inadequate in addressing inequality in the employment context in South Africa. As Ngcukaitobi points out, South Africa's labour market has been identified as "the leading driver of inequality". He also points out that a situation of inequality "reduces trust and is ultimately destructive of the notion of community or society" (Ngcukaitobi 2013: 842-843). It is this inequality that will continue to stoke the fires of violent industrial relations in South Africa for as Zizek reminds us "People do not rebel when 'things are really bad' but when their expectations are disappointed" (Zizek 2014b: 20).

Nowhere was this clearer than at Marikana in August 2012, where the past re-enacted itself as the present.

\section{Concluding remarks}

It is the view of the authors that South Africa's democracy started off on the wrong foot - firmly rooted in an industrial relations system which was heavily reliant on cheap labour. South Africa is currently gripped by a sense of political inertia, with a government unable, or at the very least unwilling, to make tough economic decisions which may ruffle the feathers of its dovetailed alliance partners. Marikana was a natural consequence of this system which has, for all its advancement of core employment rights over the last 20 years, still been unable to arrest the increased rates of unemployment, incidence of industrial action or the growing gulf of inequality in South Africa's broader society.

Ricoeur compels us to remember the past, for justice demands the victims to be remembered, but also because the past shapes our present. This seems to be true when looking at the convincing argument of Hyslop that the government's past reactions have left scars on South Africa's legal and political system that made Marikana possible. Unfortunately the events of the past appear to have indeed been forgotten, as can been seen in the history of trauma repeating itself. Thus the fact that we have forgotten is in itself an injustice, brought about by 
ideological power politics. This has allowed every traumatic event of this kind to declare itself as a "Year Zero", effectively wiping the memory of not only what happened before it, but also the memory of itself.

Violence necessarily involves the law. Whilst the position of Benjamin is accepted that positivism can make pronouncements regarding the strict legality of violence, his dismissal of natural law should be rejected. In following Ricoeur's reasoning that justice is the virtue that "opens" the self-containment of all others, natural law becomes equally important in order to judge violence. Whilst natural law might regard extra-legal considerations, these considerations can eventually be considered so important that they make their way into the legal system.

When violence and law come into contact, this violence can either be in service of law, or directed against it. It is in this sense that we can speak of law-creating or law-preserving violence. Whether the violence ultimately serves the ends of government and capital best, or perhaps in the long run that of labour, the ultimate result will be that the past will once again be forgotten and that the new (re)stated law will be a new law with new subjects. Law as a system can thus not remember the injustices of the past. Ricoeur's call to remember must thus be answered by us, the post-traumatic subjects. Brassey reminds us that the Marikana Commission of Enquiry will have its shortcomings in remembering the past, considering the present and planning the future:

[...] we should not expect an in-depth examination of the social pathologies that underlie the events, and for this we shall have to turn to the work of sociologists and social commentators. Equally, we should not expect the commission to devote much time to the structures of industrial relations or the processes of labour law that underpin them. (Brassey 2013: 823).

It is only through remembrance that the true value and significance of an event such as Marikana can be judged. It can only truly come into being through hindsight and ex post facto interpretation. A true event changes the entire landscape in which it occurred, and its interpretation cannot help but change the predominant narrative that had existed prior to its occurrence. The question then becomes obvious: was Marikana the paradigm shift that qualifies it to be a truly revolutionary event? It is perhaps still too early to say conclusively. If it retroactively becomes the creational myth for a political shift symbolised by the Economic Freedom Fighters (EFF), then it might well be. If on the other hand one 
looks at how similar it has been to violent mining incidents in the past, it could simply be a matter of "business as usual" for the South African mining industry, a cycle that keeps repeating itself because of our inability to remember.

Marikana could very well be simply another obtuse memory in South Africa's already chequered history. Viewed in this sense, Marikana is neither the start nor the end of violent strike repression and "control" in South Africa. Will the workers simply return to their benches defeated, humiliated and too broken to look each other in the eye, like Camus' Silent Men? And when they return home in the evening, like the protagonist Yvars, simply repeat the words of Zizek: "I nonetheless might think it was an event, but in fact it was the normal run of things" (Zizek 2014a: 162).

\section{Bibliography}

Alexander, P; Lekgowa, T; Mmope, B; Sinwell, L and B Xezwi (2012), Marikana A View from the Mountain and a Case to Answer. Johannesburg: Jacana.

Alexander, P (2013), "Marikana, turning point in South African history", Review of African Political Economy, Vol 40, No 138, pp 605-619.

Alexander, P (2014), "Marikana Shows Gaps in Piketty Thesis", Mail \& Guardian, 7 October.

Benjamin, W (1978), Reflections: Essays, Aphorisms, Autobiographical Writings. New York: Schocken.

Bond, P (2013), "Debt, Uneven Development and Capitalist Crisis in South Africa: from Moody's macroeconomic monitoring to Marikana microfinance mashonisas", Third World Quarterly, Vol 34, No 4, pp 569-592.

Brassey, M (2012), "Fixing the Laws that Govern the Labour Market", Industrial Law Journal, Vol 33, p 1.

Brassey, M (2013), "Labour Law After Marikana: Is Institutionalized Collective Bargaining in SA Wilting? If So, Should We Be Glad or Sad?", Industrial Law Journal, Vol 34, p 823.

Chinguno, C (2013), "Marikana: fragmentation, precariousness, strike violence and solidarity", Review of African Political Economy, Vol 40, No 138, pp 639-646.

Couzens, T (2014), The Great Silence - From Mushroom Valley to Delville Wood, South African Forces in World War One. Johannesburg: Art Publishers/ Times Media.

Davies, P and M Freedland (eds) (1983), Kahn-Freund's Labour and the Law ( $3^{\text {rd }}$ Edition). London: Stevens \& Sons. 
Dlangamandla, F, Jika, T, Ledwaba, L, Mosamo, S, Saba, A and L Sadiki (2013), We Are Going to Kill Each Other Today - The Marikana Story. Cape Town: Tafelberg.

Du Toit, D (2007), "What is the Future of Collective Bargaining (and Labour Law) in South Africa?", Industrial Law Journal, Vol 28, p 1405.

EWN, (3 July 2014), NUMSA strike: Vandalism, intimidation continues. (Available at: $\quad$ http://ewn.co.za/2014/07/03/Numsa-strike-Vandalism-and-intimidationcontinue, last accessed 17 October 2014.)

IOL, (3 July 2014), Dog Torched in NUMSA rampage. (Available at: http://www.iol. co.za/the-star/dog-torched-in-numsa-rampage-1.1713976\#.VEEMe1ckJDs, last accessed 17 October 2014.)

Letsoalo, M (2012), "NUM Plans Disciplinary Action over Baleni Salary Leak", Mail \& Guardian, 24 July.

MacShane, D (2012), "Marikana is a reminder of the apartheid years", New Statesman, 7 September.

Mavuso, Z (2014), "Review of South Africa's strike-prone dispute resolution approach urged", Mining Weekly, 29 August.

Myburgh, A (2013), The Failure to Obey Interdicts Prohibiting Strikes and Violence: The Implications for Labour Law and the Rule of Law - Tim Mills Memorial Talk, Cliffe Dekker Hofmeyr Auditorium, 23 July.

Ngcukaitobi, T (2013), "Strike Law, Structural Violence and Inequality in the Platinum Hills of Marikana", Industrial Law Journal, Vol 34, p 836.

Piketty, T (2014), Capital in the Twenty-First Century. London: Harvard University Press.

Ricoeur, P (2000), The Just. Chicago and London: University of Chicago Press.

Ricoeur, P (2004), Memory, History, Forgetting. Chicago and London: University of Chicago Press.

The South African Democracy Education Trust (2004), The Road to Democracy in South Africa, Volume 2. Pretoria: UNISA Press.

Zizek, S (2010), "History against Historicism", European Journal of English Studies, 9 August, Vol 4, No 2, pp 101-110.

Zizek, S (2014a), Event: Philosophy in Transit. London: Penguin.

Zizek, S (2014b), Trouble in Paradise - From the End of History to the End of Capitalism. London: Penguin

Zizek, S (n.d.), "Language, Violence and Non-Violence", International Journal of Zizek Studies, Vol 2, No 3, pp 1-12.

\section{Case Law}

Food \& Allied Workers Union on behalf of Kapesi \& Others v Premier Foods Ltd ta 
Blue Ribbon Salt River (2012) 33 ILJ 1779 (LAC).

Kem-Lin Fashions CC v Brunton \& another (2001) 22 ILJ 109 (LAC).

Tsogo Sun Casinos (Pty) Ltd ta Montecasino v Future of SA Workers Union \& Others (2012) 33 ILJ 998 (LC). 